\title{
FIXTURING AND HANDLING OF MINIATURE COMPONENTS
}

Published September 1976

Project Leader:

L. K. Gillespie

Department 822

Project Team:

C. P. Rome

PDO 6984735

Topical Report
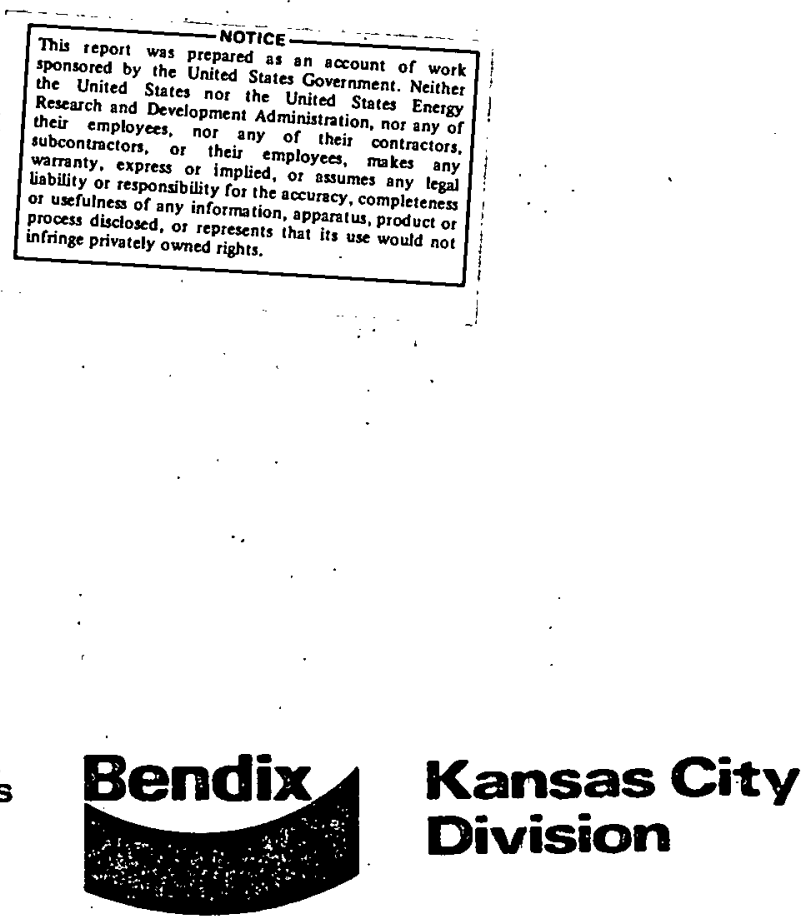


\section{DISCLAIMER}

This report was prepared as an account of work sponsored by an agency of the United States Government. Neither the United States Government nor any agency Thereof, nor any of their employees, makes any warranty, express or implied, or assumes any legal liability or responsibility for the accuracy, completeness, or usefulness of any information, apparatus, product, or process disclosed, or represents that its use would not infringe privately owned rights. Reference herein to any specific commercial product, process, or service by trade name, trademark, manufacturer, or otherwise does not necessarily constitute or imply its endorsement, recommendation, or favoring by the United States Government or any agency thereof. The views and opinions of authors expressed herein do not necessarily state or reflect those of the United States Government or any agency thereof. 


\section{DISCLAIMER}

Portions of this document may be illegible in electronic image products. Images are produced from the best available original document. 
FIXTURING AND HANDLING OF MINIATURE COMPONENTS

BDX-613-1482, UNCLASSIFIED Topical Report, Published September 1976

Prepared by L. K. Gillespie, D/822, under PDO 6984735

The fixturing, clamping, and handling of miniature precision parts during manufacture are often time-consuming and therefore expensive. In a study of 30 approaches to these operations, the use of a tooling boss which is later machined away was found to have widespread application in preventing part damage and eliminating many of the other problems encountered. Penciltype magnets with built-in release mechanisms also have alleviated some of the handling problems.

This report was prepared as an account of work sponsored by the United States Government. Neither the United States nor the United States Energy Research and Development Administration, nor any of their employees, nor any of their contractors, subcontractors, or their employees, makes any warranty, express or implied, or assumes any legal liability or responsibility for the accuracy, completeness or usefulness of any information, apparatus, product or process disclosed, or represents that its use would not infringe privately owned rights.
THE BENDIX CORPORATION

KANSAS CITY" DIVISION

P.O. BOX 1159

KANSAS CITY, MISSOURI 64141

A prime contractor for the United States Energy Research and Development Administration Contract Number E(29-1)-613 USERDA 


\section{CONTENTS}

Section . . . . . Page

SUMMARY • . . . . . . . . . . . . . . . . . . . . 5

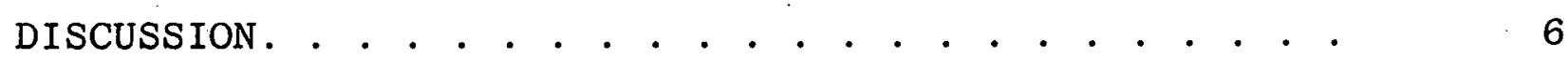

SCOPE AND PURPOSE . . . . . . . . . . . . . . . . . 6

PRIOR WORK. . . . . . . . . . . . . . . . . 6

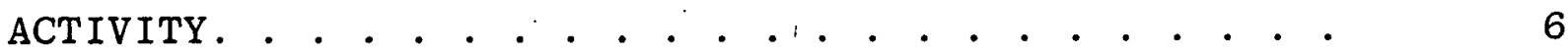

Background. . . . . . . . . . . . . . . . . . . 6

Workpiece Configuration . . . . . . . . . . . . . 8

Major Handling and Fixturing Elements . . . . . . . 9

Basic Approaches to Fixturing . . . . . . . . . . . 9

Locating Parts in Fixtures. . . . . . . . . . . . . 12

Clamping Techniques . . . . . . . . . . . . . . 15

Handling of Small Parts . . . . . . . . . . . . . . 22

Implementation of Fixturing and Handling

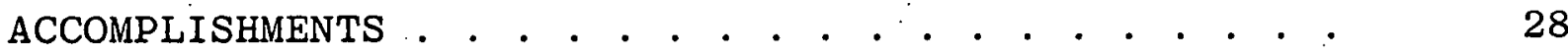

REFERENCES. . . . . . . . . . . . . . . . . . . . . 29

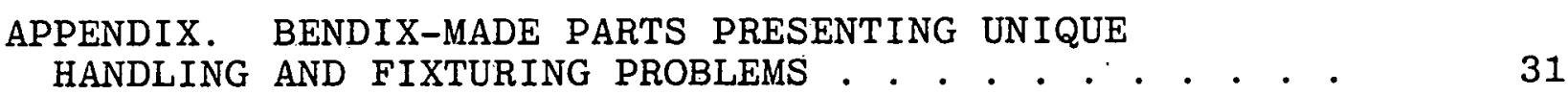

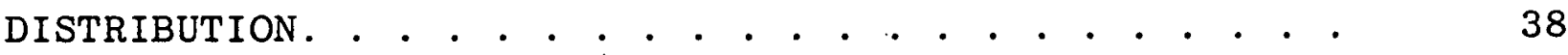




\section{ILLUSTRATIONS}

Figure

Page

1

Approaches to the Minimization of Production

Time

Example Showing Parts Being Produced in a Strip (P-91818).

Example Showing Tooling Holes External to

Finished Part. . . . . . . . . . . . . .

Parts Produced Through the Use of Tooling Bosses (P-91819) . . . . . . . . . . . . .

Typical Thumbscrew and Strap Clamps Used in Tooling for Short Runs of Parts . . . .

\section{TABLES}

Number

1

2

3

4

5

6
Basic Approaches to Fixturing. . . . . . . Handling Time Saved for Production Quantities of Parts. . . . . . . . . .

Annual Savings Through Elimination of

Wasted Time. . . . . . . . . . . . .

Clamping Techniques. . . . . . . . . . . .

References for Sources of Information on Cutting Forces . . . . . . . . . . . .

Approaches to the Handling of Miniature

Parts. . . . . . . . . . . . . . . . .
Page 


\section{SUMMARY}

Fixturing and handling of miniature precision parts in a manner to prevent them from being damaged require special consideration because of the small size and close tolerances of the parts. Thin and soft parts are easily damaged by the use of unsuitable clamping and handling methods. Because of their size, small parts are difficult to install in fixtures. Clamping is difficult because the clamps that provide the required holding force tend to cover a large portion of the part. Small-diameter locating pins in fixtures are easily bent by cutting or clamping forces. Parts which are small and thin are difficult to pick up and transport by conventional techniques.

An analysis of available fixturing and handling methods revealed 30 approaches that are applicable to small parts; the majority of these have limited application for very small parts. Electrostatic, electromagnetic, and vacuum chucks require larger surface areas than are typically available on miniature parts. Strap clamps, thumbscrews, and most hydraulic or pneumatic clamps often interfere with continuous cutting. Adhesive-bonding and potting in low-melting-temperature alloys require time-consuming secondary operations for pouring, bonding, and removal.

The use of tooling bosses which are machined away after the part is completed was found to have widespread application in eliminating most of the fixturing, clamping, and handling problems that are encountered in the manufacture of many miniature precision parts. The use of small pencil-type magnets with a built-in release mechanism which is not affected by residual magnetism in the parts was found to minimize some of the handling problems.

Most of the applicable techniques studied have been employed at the Bendix Kansas City Division for production lots of parts. 


\section{DISCUSSION}

\section{SCOPE AND PURPOSE}

The production of miniature components poses a number of unique fixturing and handling problems. In particular, paper-thin or precision-sculptured parts which are smaller than pencil erasers require a great amount of time and care. This project therefore was initiated to identify production-tooling concepts which could minimize part damage and handling time. Specifically, clamping techniques, fixturing concepts, methods of locating parts, and handling techniques were investigated.

\section{PRIOR WORK}

Although two studies have been made concerning the machining techniques applicable to the cutting forces involved in the production of miniature parts, 1,2 no prior work on fixturing and handling problems has been reported by Bendix Kansas City.

\section{ACTIVITY}

\section{Background}

The productivity of manufacturing operations is of continuing interest in any metal-cutting facility. While many advances have been made in machine-tool capabilities, cutting-tool life, and automation in the production of high-volume components, few significant advances have occurred in other related fields.

In the production of low-quantity batch-lots of small parts, the loading, unloading, and handling of the parts can require significantly more time than the actual machining time. This is particularly true of precision parts which require more than one machining operation and which are smaller than 0.250 inch $(6.35 \mathrm{~mm})$ or thinner than 0.010 inch $(254 \mu \mathrm{m})$. With parts such as these, which require milling, drilling, and grinding operations, the loading and unloading time constitutes up to 75 percent of the total production time. Thus the minimization of cutting time, which is the traditional approach in improving productivity, is less effective than other approaches (Figure 1). The following observation recently was made by the chairman of one of the largest machine-tool builders in the United States.

The average workpiece in a batch-type production shop spends only 5 percent of its time in production machines, and productive work is being done on the part only 30 percent of this actual time in the machines. 3 


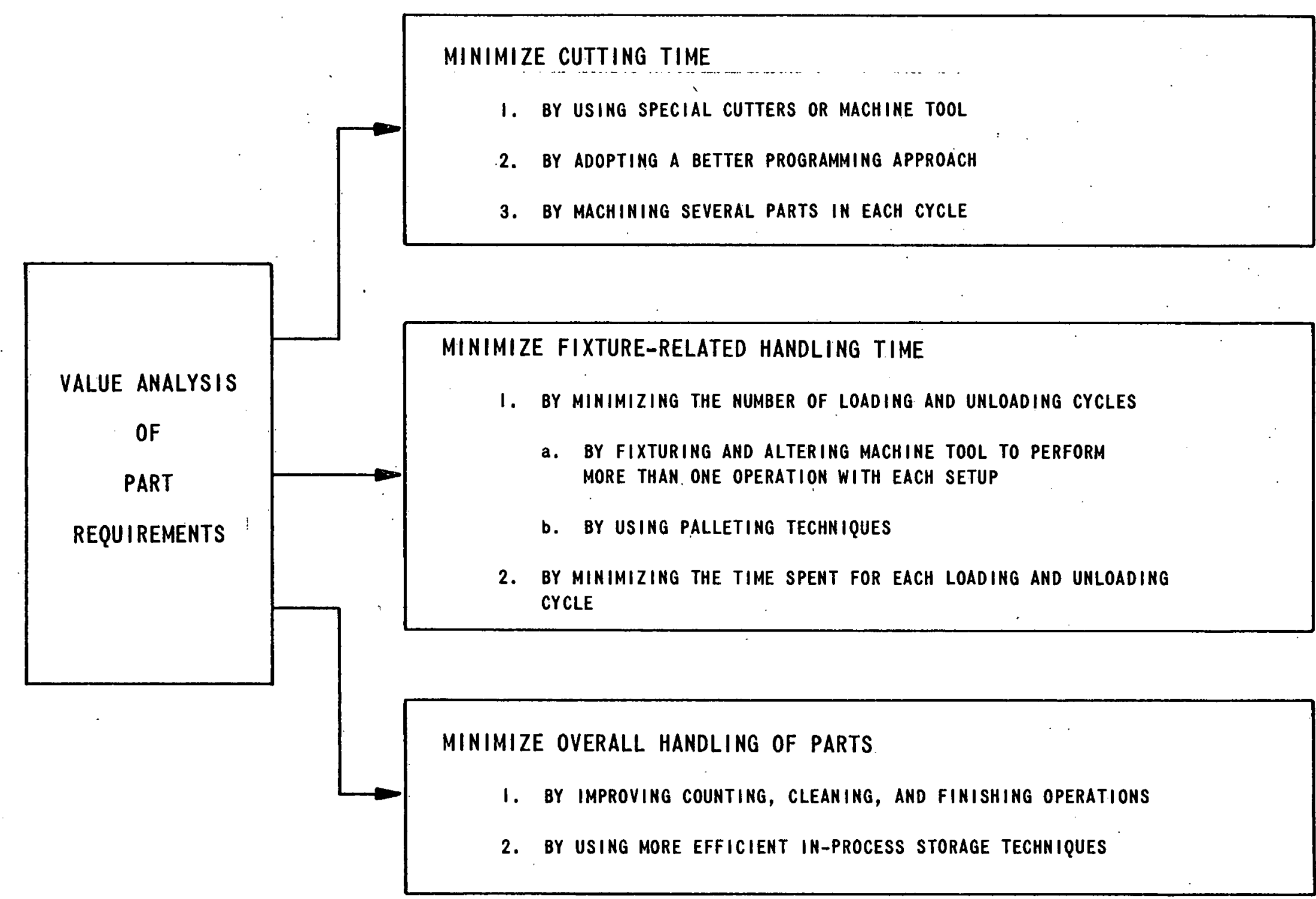

Figure 1. Approaches to the Minimization of Production Time 
A great amount of finger dexterity is required in the handling of minute parts. This alone significantly increases the handling time. Many of the parts have thin sections, precision finishes, or near-zero tolerances which also necessitate extra handling care.

The combination of a small part size and close tolerances requires extra care and time in placing the parts in fixtures. As an example, locating a part on a 0.016 -inch-diameter $(0.406 \mathrm{~mm})$ pin and assuring that it is seated flush with the bottom of the fixture is much like threading a needle with a thread which is only 0.0005 inch $(12.7 \mu \mathrm{m})$ smaller than the eye of the needle.

The production of low quantities of parts in batch lots, as contrasted with the continuous production of parts, economically rules out much of the automation that is employed in other industries.

Workpiece Configuration

In searching for better approaches to the fixturing and handling of small parts, one of the first obvious steps is to define the features that are common to many of the parts. However, in analyzing the configuration of parts used in Bendix electromechanical components, few common fixturing elements were found. Some of the part configurations which present some form of fixturing or handling problem are illustrated in the Appendix. Typical handling and fixturing problems for thin, flat parts which, for example, are 0.002 inch $(50.8 \mu \mathrm{m})$ in thickness might include the following considerations.

- Picking up parts from in-process containers (Any moisture present produces high-surface-tension holding forces.);

- Placing the part on tooling pins when the holes are small (perhaps 0.030 inch or $0.75 \mathrm{~mm}$ in diameter) and the tooling pins are within 0.0005 inch $(12.7 \mu \mathrm{m})$ of the hole size;

- Handling the parts in a manner to prevent damage; and

- Separating the parts for cleaning and counting operations.

The following typical problems are encountered in the handing and fixturing of small milled parts.

Designing a clamp to hold the part (Because of their size, most strap-- or toe-type clamps mask much of the part.);

Providing clamping pressure that will prevent the movement of small precision parts without distorting them; 
Providing locating features that are not bent by cutting forces;

- Providing rapid clamping techniques; and

Providing rapid part-insertion and part-removal techniques. Major Handling and Fixturing Elements

The following major elements must be considered in the handling and fixturing of small precision parts.

- A variety of possible techniques to transfer the parts from in-process shipping containers to the fixture and back.

- A fixture configuration to provide support for and rapid setup of the part, and to provide clearance for burrs (The use of multiple fixture stations and pallets must also be considered. );

- Techniques to accurately locate the parts in the fixture through the use of tooling holes, external contour, or both; and

- A variety of possible clamping techniques.

Of these, the part-location techniques offer the least flexibility.

Basic Approaches to Fixturing

An analysis of the basic approaches to fixturing indicates that the use of duplicate fixtures and the production of parts in strips offer the greatest potential for minimizing nonproductive handling time (Table 1).

The use of duplicate fixtures allows an operator to load one part while the machine is cutting another. The machine-tool cuttingrate then becomes the productivity-limiting factor. While for many parts this approach offers some advantages, it also has some noticeable disadvantages: tooling costs are nearly doubled since two fixtures are required; the approach is effective only on machines which do not require hand-feeding; and loss in dimensional repeatability occurs from the use of multiple tools because of dimensional differences between the fixtures.

For an initial approximation, the economic break-even point in the use of this approach is the point at which the saving in handling time equals the cost of the fixture. If a duplicate fixture can be made for $\$ 1500$, the maximum number of parts to be 
Table 1. Basic Approaches to Fixturing

\begin{tabular}{|c|c|c|}
\hline Approach & Advantages & Limitations \\
\hline \multirow{4}{*}{$\begin{array}{l}\text { All fixtures used to produce } \\
\text { a part locate from the } \\
\text { same part surfaces or } \\
\text { locating details }\end{array}$} & $\begin{array}{l}\text { Tolerance losses } \\
\text { minimized }\end{array}$ & \multirow[t]{5}{*}{$\begin{array}{l}\text { Part geometry may not be } \\
\text { suitable }\end{array}$} \\
\hline & $\begin{array}{l}\text { Confusion on part } \\
\text { orientation minimized }\end{array}$ & \\
\hline & $\begin{array}{l}\text { Uniform clamping } \\
\text { approach accommodated } \\
\text { more readily }\end{array}$ & \\
\hline & Tooling costs minimized & \\
\hline $\begin{array}{l}\text { Utilize separate fixture for } \\
\text { each operation }\end{array}$ & $\begin{array}{l}\text { Offers more flexibility } \\
\text { in tool design and } \\
\text { fabrication }\end{array}$ & \\
\hline \multirow[t]{4}{*}{$\begin{array}{l}\text { Utilize duplicate or } \\
\text { interchangeable fixtures } \\
\text { (Example: palleting) }\end{array}$} & \multirow{4}{*}{$\begin{array}{l}\text { Loading/unloading can } \\
\text { be performed during } \\
\text { machine cycle on } \\
\text { machines having } \\
\text { mechanized feeding } \\
\text { Part can be shuttled to } \\
\text { two or three machining } \\
\text { operations before } \\
\text { unloading }\end{array}$} & \multirow{3}{*}{$\begin{array}{l}\text { Tool costs are in } \\
\text { proportion to number of } \\
\text { duplicates made } \\
\text { Paperwork system may not } \\
\text { accept a lot of parts } \\
\text { crossing two or more } \\
\text { machines before they are } \\
\text { completed on the first } \\
\text { machine }\end{array}$} \\
\hline & & \\
\hline & & \\
\hline & & $\begin{array}{l}\text { Tolerance is sacrificed } \\
\text { when two or more } \\
\text { pallets are used }\end{array}$ \\
\hline $\begin{array}{l}\text { Design fixture so that } \\
\text { multiple parts can be } \\
\text { machined in one setup }\end{array}$ & Cutting time minimized & $\begin{array}{l}\text { May present clamping } \\
\text { difficulties since parts } \\
\text { will vary in size }\end{array}$ \\
\hline
\end{tabular}


Table 1 Continued. Basic Approaches to Fixturing

\begin{tabular}{|c|c|c|}
\hline Approach & Advantages & Limitations \\
\hline $\begin{array}{l}\text { a. Load loose parts into } \\
\text { fixture }\end{array}$ & & $\begin{array}{l}\text { Multiple locations of } \\
\text { parts result in } \\
\text { tolerance loss }\end{array}$ \\
\hline $\begin{array}{l}\text { b. Load strip of parts } \\
\text { into fixture }\end{array}$ & $\begin{array}{l}\text { The use of one strip } \\
\text { rather than loose } \\
\text { parts minimizes } \\
\text { loading time } \\
\text { Handling and orienting } \\
\text { time is minimized } \\
\text { Tolerances lost to } \\
\text { fixturing are less } \\
\text { than in Approach a. }\end{array}$ & $\begin{array}{l}\text { Part geometry may not be } \\
\text { suitable } \\
\text { Clamping for a strip may } \\
\text { not be as firm as for } \\
\text { parts machined singly }\end{array}$ \\
\hline
\end{tabular}


machined is 1000 , and the fixture saves 90 seconds per part, the labor rate must be at least $\$ 60$ per hour for this approach to be economical. Tables 2 and 3 provide additional data which are useful in evaluating the economics of the handling time.

For the manufacture of small parts, more than one part may be machined from a single strip of metal. If the parts remain attached to the strip until the final operation, only one loadunload operation is required for the entire group of parts on each strip.: In addition, the strip often provides greater clamping accuracy because of the larger surface area. Figure 2 illustrates the application of this approach to a component manufactured by the Bendix Kansas City Division. Seven separate operations are performed on these parts while they remain attached to the strip. This type of approach has been described in more detail by another author. ${ }^{4}$

If a fixture for the production of five parts in a strip were no more expensive than fixtures for the production of the individual parts, the strip approach would eliminate 80 percent of the handling time. For most metals, the cost of material wasted by the strip approach to the production of miniature parts would be insignificant.

Locating Parts in Fixtures

One of the more time-consuming elements in the fixturing and handling of small parts involves the positioning of the parts on the locating devices of the fixture. Parts may be located on the fixture by any of the following four methods:

- External part contour;

- Datum holes and pins:;

- Tooling holes which are external to the finished part; and

- Tooling bosses.

As datum-hole sizes and tolerances become smaller, placing the part over the locating feature becomes more difficult. This often becomes a major problem with thin aluminum parts because the thickness and shape of the part may not allow lead-in chamfers on tooling pins. In addition, thin parts can become distorted from forcing them over tooling pins.

When parts have external contours with tolerances of only 0.001 inch $(25.4 \mu \mathrm{m})$, the locating pins can be only 0.0002 inch $(5.08 \mu \mathrm{m})$ smaller than the datum holes. When these holes are only 0.020 inch $(0.50 \mathrm{~mm})$ in diameter, unusual dexterity is required to load the 
Table 2. Handling Time Saved for Production Quantities of Parts

\begin{tabular}{llllll}
\hline \multirow{2}{*}{$\begin{array}{l}\text { Time Saved } \\
\text { Per Part } \\
\text { (Seconds) }\end{array}$} & $\begin{array}{l}\text { Time Saved for Number of Parts } \\
\text { (Hours) }\end{array}$ & $\begin{array}{l}500 \\
\text { (Hours) }\end{array}$ & $\begin{array}{l}1000 \\
\text { (Hours) }\end{array}$ & $\begin{array}{l}5000 \\
\text { (Hours) }\end{array}$ & $\begin{array}{l}10,000 \\
\text { (Hours) }\end{array}$ \\
\cline { 2 - 6 } 10 & 0.28 & 1.39 & 2.8 & 13.9 & 28 \\
60 & 1.67 & 8.35 & 16.7 & 83.5 & 167 \\
90 & 2.50 & 12.50 & 25.0 & 125.0 & 250 \\
120 & 3.33 & 16.65 & 33.3 & 166.5 & 333 \\
180 & 5.00 & 25.00 & 50.0 & 250.0 & 500 \\
240 & 6.67 & 33.30 & 66.7 & 333.0 & 667 \\
\hline
\end{tabular}

workpieces. Furthermore, removing these parts from the fixture may require as much skill as loading them, since most of the parts are so small that cutouts for fingerholds cannot be employed. The cutouts often require the removal of material that is needed to support the parts.

Although many parts can be located from external contours, many more, because of tolerances, cannot be approached in this manner. If the approach can be used, it does have the advantage that part insertion is easier because the largest features of the part are used for part-location. Dropping a 0.250 -inch-diameter ( $6.35 \mathrm{~mm}$ ) part into a $0.0002-i n c h$-larger $(5.08 \mu \mathrm{m})$ cavity can be easier than placing it on a small pin, and this method eliminates the possibility of accidentally bending small pins. However, because parts can easily become locked in a tight-fitting cavity, the use of locating pins is often much easier.

In some cases, a blank much larger than that required for the part can be utilized during manufacture, and large tooling holes can be inserted in an area which lies outside the finished part (Figure 3). If closely controlled, the long spacing between the tooling holes provides more accurate orientation of the part than is possible through the use of closely spaced holes. When this approach is used, the small holes that are integral to the part are used only in the final manufacturing operation.

For many parts, the use of a tooling boss on the part is the most convenient approach. By this method, the boss, which can be of any convenient size, is used to position the part, and it also serves as a solid surface for clamping: After the part is 
Table 3. Annual Savings Through Elimination of Wasted Time

\begin{tabular}{|c|c|c|c|c|c|c|}
\hline \multirow{2}{*}{$\begin{array}{l}\text { Time Saved } \\
\text { Per Day } \\
\text { (Minutes) }\end{array}$} & \multicolumn{2}{|c|}{ Annual Savings } & \multicolumn{4}{|c|}{ Indicated Hourly Labor Rate* } \\
\hline & $\begin{array}{l}\$ 5 \\
(\$)\end{array}$ & $\begin{array}{l}\$ 6 \\
(\$)\end{array}$ & $\begin{array}{l}\$ 7 \\
(\$)\end{array}$ & $\begin{array}{l}\$ 8 \\
(\$)\end{array}$ & $\begin{array}{l}\$ 9 \\
(\$)\end{array}$ & $\begin{array}{l}\$ 10 \\
(\$)\end{array}$ \\
\hline 5 & 108 & 130 & 151 & 173 & 194 & 216 \\
\hline 10 & 217 & 260 & 304 & 347 & 391 & 434 \\
\hline 20 & 434 & 521 & 608 & 694 & 781 & 868 \\
\hline 40 & 868 & 1042 & 1215 & 1389 & 1562 & 1736 \\
\hline 60 & 1301 & 1562 & 1821 & 2082 & 2342 & 2602 \\
\hline
\end{tabular}




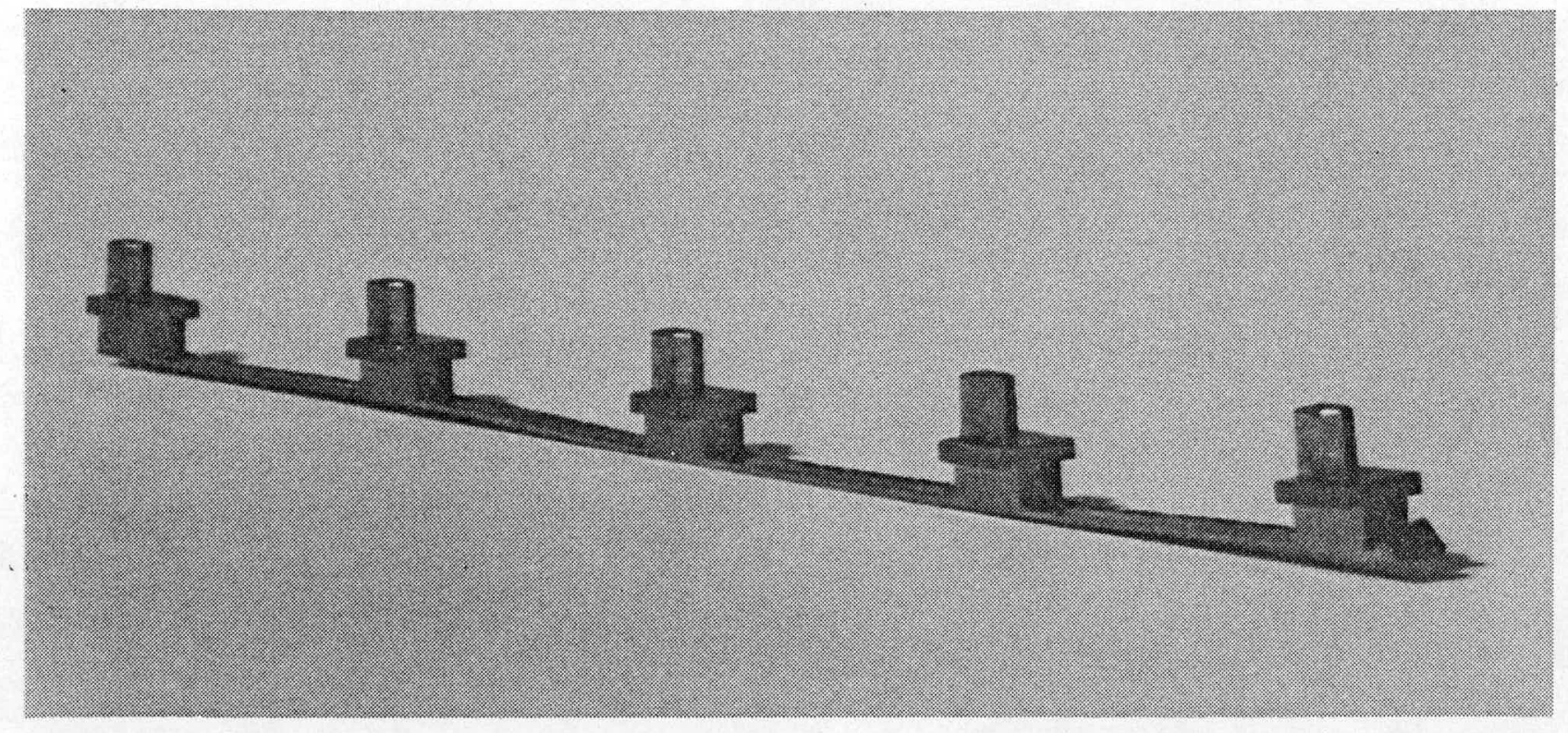

Figure 2. Example Showing Parts Being Produced in a Strip

finished, it is placed in a lathe and a cut-off tool is used to separate the workpiece from the boss. A grinding or facing operation then removes the small projection left from the cut-off operation. This approach is particularly advantageous for parts which are completely machined on N/C equipment, although it also can be easily used for multiple-operation applications. Figure 4 shows three typical applications that have been used at Bendix Kansas City.

\section{Clamping Techniques}

The biggest single problem in the fixturing and handling of small parts is to find suitable clamping techniques. The clamps used must meet the following requirements:

- Be relatively quick to apply and remove;

- Not damage the part;

- Be small enough not to interfere with the cutters; and

- Be strong enough to prevent part movement.

Traditionally, simple strap or toe clamps have been used on tooling for short runs of parts because of their low cost (Figure 5). This kind of clamping, however, requires an operator to adjust one or two setscrews or thumbscrews which typically require from 10 to 30 seconds per part; for some parts, clamping may require considerably more time than this. 


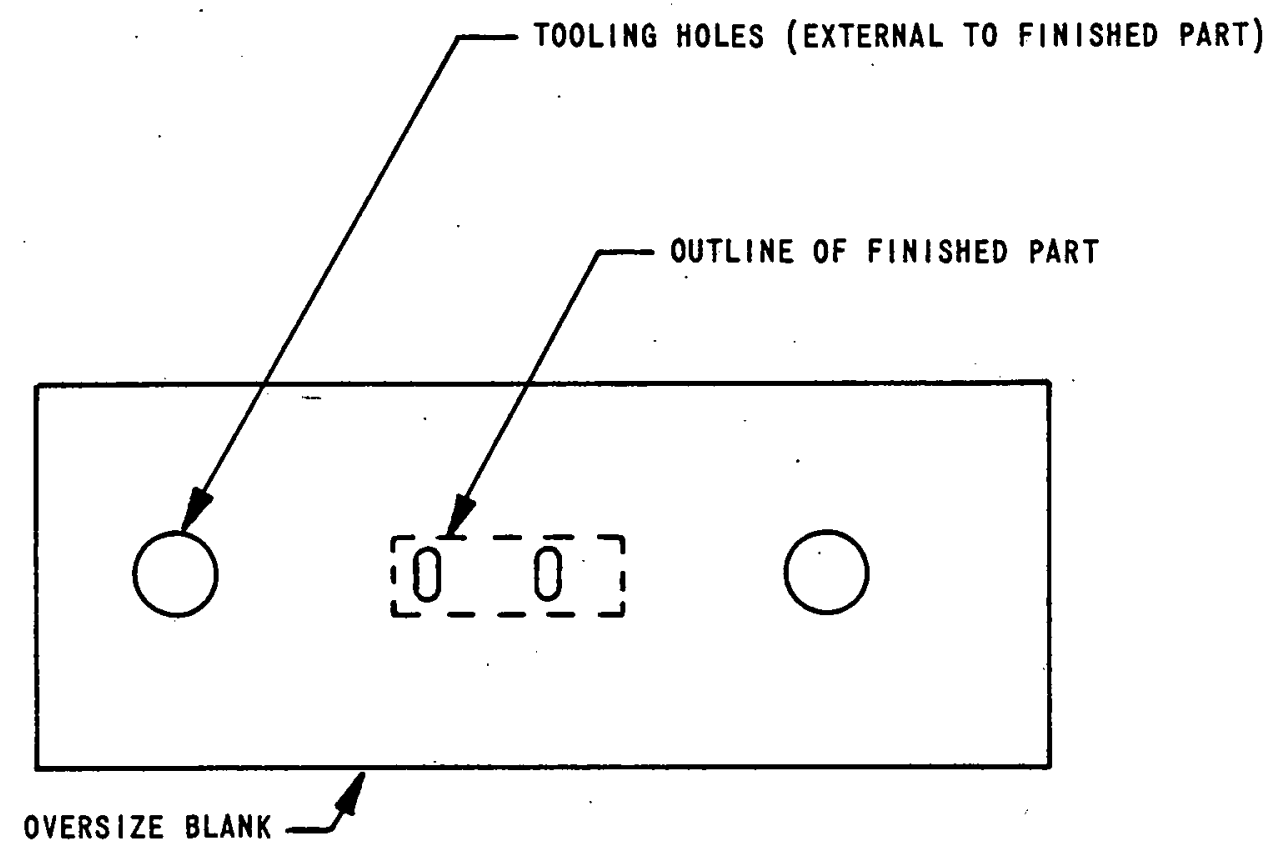

Figure 3. Example Showing Tooling Holes External to Finished Part

From the standpoint of providing quick clamping and release, the first eight techniques shown in Table 4 offer nearly equal response time. Materials which retain magnetic fields, however, will require a somewhat longer time for removal from magnetic chucks. While magnetic, electrostatic, and vacuum chucks are generally used for flat parts, vacuum chucks have been used successfully to hold thin-flanged aluminum parts on the lathe. All of these approaches have the advantage of requiring no projections above the part which would interfere with the cutting tools.

The temporary bonding of parts to a fixture by the use of adhesives has been used successfully for both metals and ceramic plates. (Eastman 910 epoxy, Argüeso's Rigidax, and Devcon's Zipgrip have been used for holding metals.) Although this approach requires two additional manufacturing operations, it eliminates the problem of clamping brittle or easily distorted parts. ${ }^{5}$ For some parts, there is an advantage in completely covering or filling the part with a low-melting-temperature alloy. (Argüeso's Rigidax and the Cerro Corporation's Cerrolow and Cerrobend are examples of such alloys.) In general, the use of adhesives or low-melting-temperature alloys increases the handling time for the parts; however, when groups of 20 or 30 parts are clamped in one unit by the use of these techniques, some saving in time may occur. 


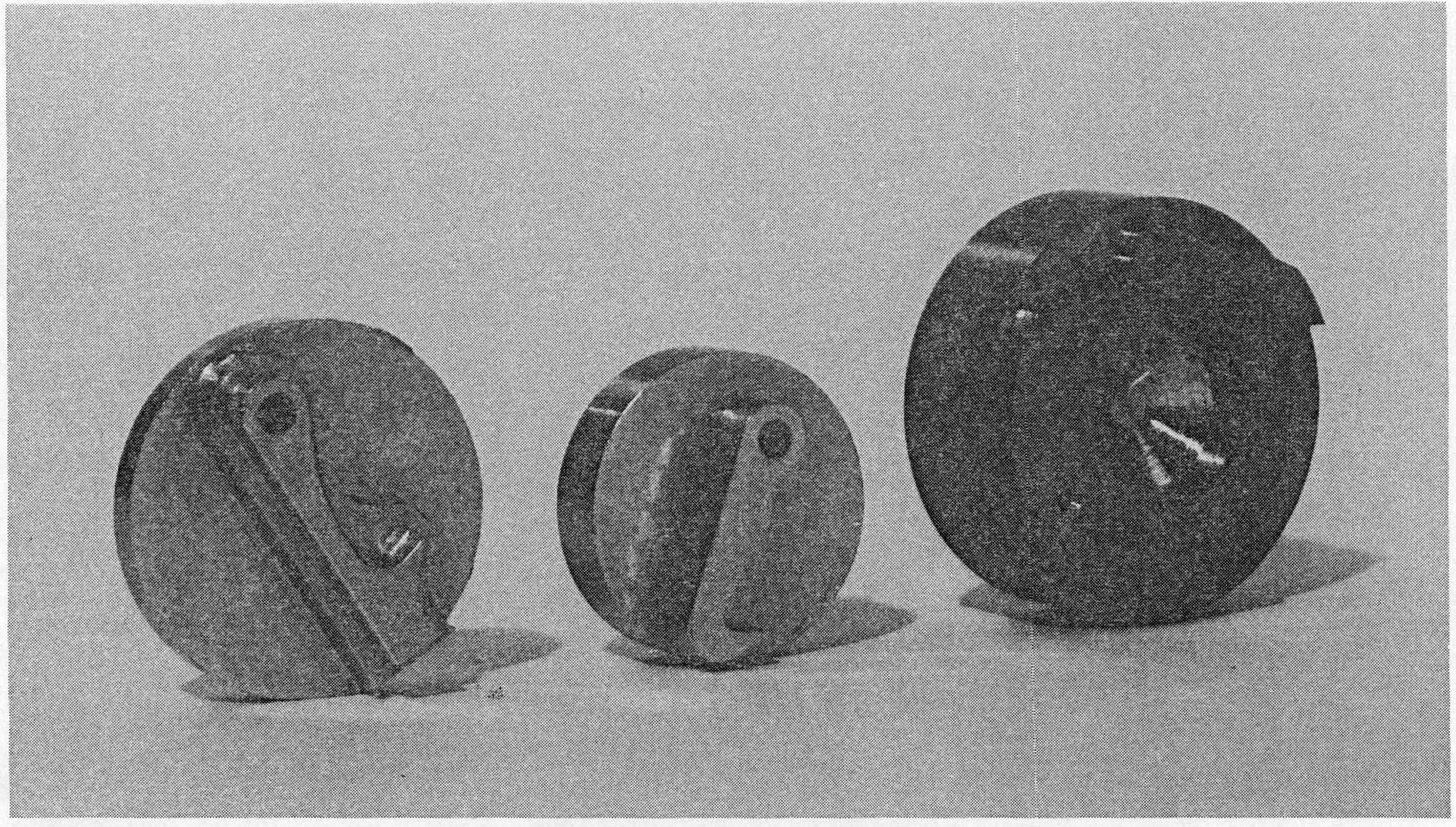

Figure 4. Parts Produced Through the Use of Tooling Bosses 


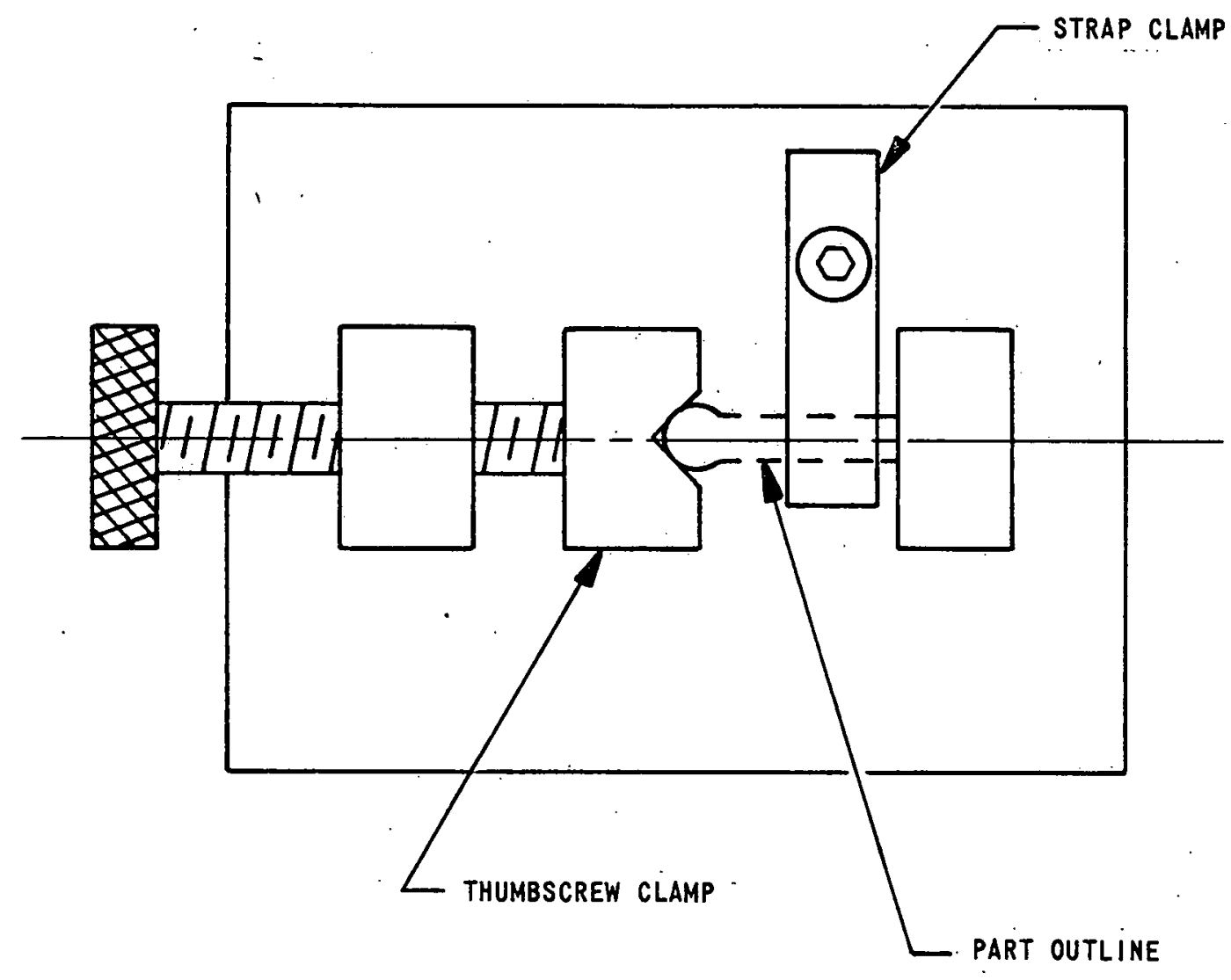

Figure 5. Typical Thumbscrew and Strap Clamps Used in Tooling for short Runs of Parts

Part deformation is possible when using toggle, strap, thumbscrew, or vise-jaw clamps since these devices will not accurately limit the clamping force. Consider, for example, the part shown in Figure 2. A 3/8-inch-diameter $(9.78 \mathrm{~mm})$ four-flute end $\mathrm{mill}$ is used to machine this part at a feed of 0.001 ipr $(25.4 \mu \mathrm{m} / \mathrm{rev})$ and a speed of $2000 \mathrm{rpm}$. Wilson's equation ${ }^{6}$ predicts a tangential cutting force of 146 pounds $(650 \mathrm{~N})$ in 1045 hot-rolled steel (BHN 202) for a $1 / 8-$ inch $(3.175 \mathrm{~mm})$ depth-of-cut, cutting with the full diameter. Thus the clamping forces must resist at least the following amount of force.

$F_{c u t}=\frac{396,000 \mathrm{wnf}^{1-b} \mathrm{~d}^{1-c}}{\pi C D V^{2}}$,

where

$F_{\text {cut }}=$ tangential cutting force (pounds),

$\mathrm{w}=$ radial depth-of-cut (inch), 
Table 4. Clamping Techniques

\begin{tabular}{|c|c|c|}
\hline $\begin{array}{l}\text { Technique and Typical } \\
\text { Maximum Holding Force or } \\
\text { Pressure }\end{array}$ & Advantages & Limitations \\
\hline $\begin{array}{l}\text { 1. Vacuum Chuck-- } \\
13 \text { psi }(89.6 \mathrm{kPa})\end{array}$ & $\begin{array}{l}\text { Easily accommodates } \\
\text { thin parts with large } \\
\text { surface area }\end{array}$ & Low holding force \\
\hline $\begin{array}{l}\text { 2. Toggle-Action-Cam-Lock } \\
\text { Clamp }\end{array}$ & Quick release & $\begin{array}{l}\text { May distort thin parts; } \\
\text { clamp may project too } \\
\text { high for miniature tools }\end{array}$ \\
\hline $\begin{array}{l}\text { 3. Magnetic Chuck-- } \\
1125 \text { psi }(7.76 \mathrm{MPa})\end{array}$ & $\begin{array}{l}\text { No clamps in way of } \\
\text { cutter }\end{array}$ & $\begin{array}{l}\text { Parts must be magnetic } \\
\text { and have reasonable } \\
\text { surface area }\end{array}$ \\
\hline 4. Hydraulic Clamps & Fast actuation & $\begin{array}{l}\text { Hydraulic supporting } \\
\text { equipment is large }\end{array}$ \\
\hline 5. Pneumatic Clamps & Fast actuation & \\
\hline 6. Electrostatic Chuck & $\begin{array}{l}\text { Can be used on } \\
\text { nonmagnetic materials }\end{array}$ & $\begin{array}{l}\text { Low holding force; use } \\
\text { limited to metals }\end{array}$ \\
\hline 7. Collet & Quick release & $\begin{array}{l}\text { Part geometry may not be } \\
\text { suitable }\end{array}$ \\
\hline $\begin{array}{l}\text { 8. Swivel Clamp*-- } \\
68 \text { pounds }(302 \mathrm{~N})\end{array}$ & Quick release & \\
\hline 9. Strap Clamp** & Low cost & Slow; no control of force \\
\hline 10. Centers & $\begin{array}{l}\text { No clamps in cutter } \\
\text { path }\end{array}$ & $\begin{array}{l}\text { Part geometry may limit } \\
\text { application; requires } \\
\text { additional machining } \\
\text { operations }\end{array}$ \\
\hline 11. Thumb Screws** & Low cost & Slow; no control of force \\
\hline 12. Vise Jaws & Low cost & No control of force \\
\hline
\end{tabular}


Table 4 Continued. Clamping Techniques

\begin{tabular}{lll}
$\begin{array}{l}\text { Technique and Typical } \\
\text { Maximum Holding Force or } \\
\text { Pressure }\end{array}$ & Advantages & Limitations \\
\hline $\begin{array}{l}\text { 13. Adhesive Bonding } \\
\text { 14. Potting in Low-Melting- } \\
\text { Point Alloys }\end{array}$ & $\begin{array}{l}\text { Accommodates any shape; } \\
\text { supports thin sections } \\
\text { and hard-to-reach } \\
\text { areas }\end{array}$ & $\begin{array}{c}\text { Requires subsequent } \\
\text { operating and cleaning } \\
\text { odhesions; may load } \\
\text { cutters }\end{array}$
\end{tabular}

*Hydraulic or pneumatic clamps which release and rotate 180 degrees to provide easy removal of part (Stilson Corporation miniature air-powered Rota-Clamp).

**Torque-limiting screws can be purchased for these clamps, but the selection is limited. 
n = number of teeth on the cutter,

$f=$ feed per tooth per revolution,

$b=$ material constant. (1/3),

$d$ = axial depth-of-cut (inch),

$c=$ material constant (1/6),

$C=$ material constant ( 3 , for this example),

$\mathrm{D}=$ cutter diameter (inch),

$\mathrm{V}=$ cutting velocity $\left(\mathrm{sfpm}=\frac{\pi \mathrm{DN}}{12}\right)$,

$\mathrm{a}=$ material constant $(0.125)$, and

$\mathrm{N}=\operatorname{spindle}$ speed $(\mathrm{rpm})$.

The actual forces would be greater than indicated since the 1045 steel used in the example is not as hard as the 17-4PH stainless-steel parts shown in Figure 2 . In addition, a vertical force would exist which would pull the part upward against the clamp.

If only frictional forces were used to hold the part against the fixture, the clamping force would have to be greater by the amount shown in Equation 2 .

$F_{\text {clamp }}=\frac{F_{\text {cut }}}{\mu}$,

where

$\mu=$ static coefficient of friction.

Assuming that $\mu$ were approximately 0.75 for steel on steel, a clamping force of at least 194 pounds $(865 \mathrm{~N})$ would be required.

If the available clamping area were only 0.125 by 0.064 inch ( 3.175 by $1.626 \mathrm{~mm}$ ), the clamping pressure would be approximately 25,000 psi $(174.5 \mathrm{MPa})$. Using Shawki and Abdel-Aal's data as a guide, the clamped area of the workpiece would be deformed 0.0002 inch $(5 \mu \mathrm{m})$ beyond its theoretical elastic limit. Under a clamping force of this magnitude, the use of spherical locators would result in even greater deformation.

The use of tooling bosses, external holding features, and multiple parts in a strip provide a much larger clamping surface than is available on the parts alone. In addition to making clamping 
easier, these methods significantly lower the pressure applied to the total part which, in turn, minimizes part damage. When tooling bosses are used, any damage which occurs is to the tooling boss and not to the part.

One of the major deterrents to the prevention of clamping damage has been a lack of knowledge as to how great the clamping forces should be. Similarly, little information has been published to provide engineers and tool designers with data on the forces which various types of clamping devices can exert on parts. Table 5 lists the references to be found in this report for some of the more production-oriented sources of information from which cutting forces can be predicted reasonably close. Wilson ${ }^{8}$ and Shawki and Abdel-Aal, ${ }^{7}$ however, appear to be the only individuals who have published any readily available information on clamping forces and their effects.

As previously indicated, miniature parts require the use of miniature clamps. For profiling operations, it is highly desirable that clamps be arranged so that they need not be loosened and repositioned in order to complete the cut. Unfortunately, parts without tooling bosses or similar features do require some reclamping during the machining cycle. This not only increases the clamping time, but it also introduces the risk of slightly altering the part location.

In addition to requiring potentially damaging pressures because of the small bearing surfaces involved, the clamps interfere with the movement of the machine spindle. The drilling of a $0.012-$ inch-diameter $(0.30 \mathrm{~mm})$ precision hole, for example, requires the use of the shortest possible drill. A clamp which projects 0.030 inch $(0.76 \mathrm{~mm})$ above the workpiece requires that the drill length be at least 0.030 inch, plus an additional 0.010 inch $(0.25 \mathrm{~mm})$ for clearance, plus the thickness of the workpiece. Thus the drill length required for clamp clearance alone is more than the total recommended length. (For maximum rigidity and accuracy, the drill length usually should not exceed three times the drill diameter.) This problem is even more critical when miniature end mills are used. A 0.026-inch-diameter $(0.6 \mathrm{~mm})$ end mill with 0.62 -inch $(1.57 \mathrm{~mm})$ flute length deflects 0.002 inch $(50.8 \mu \mathrm{m})$ under a 2-pound (8.89 N) cutting force. An additional length of 0.036 inch $(0 . .91 \mathrm{~mm})$ for clamp clearance allows the tool to deflect 0.009 inch $(0.23 \mathrm{~mm})$ under the same load. ${ }^{2}$ This results in a higher incidence of tool breakage and a decrease in part accuracy.

Handling of Small Parts

A typical part is handled individually at least 25 times throughout its fabrication cycle. This assumes that each part is handled twice per operation, with eight machining, deburring, or finishing 
Table 5. References for Sources

of Information on

Cutting Forces

\begin{tabular}{ll}
\hline Operation & References* \\
\hline Turning & $9 ; 10 ; 11$ \\
Drilling & $9 ; 10 ; 11 ; 12$ \\
End-Milling & 9 \\
Face-Milling & $8 ; 9$ \\
Slab-Milling & $9 ; 12 ; 13$. \\
Grinding & 14 \\
Broaching & $8 ; 9$ \\
\hline & *Numbers shown refer to \\
references listed at the end \\
of this report. \\
\hline
\end{tabular}

operations per part, two inspections, a passivation, and a final packaging. The part shown in Figure 2 is handled 12 times as a bar of five parts, 30 times as an individual part, and 34 times for inspection (assuming 100-percent inspection of all features). In addition, the parts are handled 26 times as a group. Thus each part is handled a total of 64 times. Each time, the operator must remove it from one location and carry it to another without damage or loss while maintaining some form of part orientation. As the size of the parts decrease, the time required for handling increases greatly.

As shown in the following list of typical operations, most parts pass through a variety of production steps; some parts may be cleaned, inspected, and packaged several times:

- Machining;

- Deburring;

- Cleaning;

- Heat-treating;

- Passivating or plating; 


\section{Inspection;}

\section{Counting; and}

Packaging.

Because of the large amount of handling involved, the handling equipment must be carefully considered. As shown in Table 6, ten common handling techniques are available. Fingers do not have enough dexterity to quickly pick up, orient, and place small parts such as those shown in Figure 2. Tweezers may be used, and often are, but they can easily damage the threads on minute threaded parts, and the orienting of some parts can be very slow. Although the breaking of the bond between a magnet and a part has been a problem with many parts, pencil-type magnets having built-in release mechanisms are now available (National Camera Inc., Englewood, Colorado).

Vacuum probes provide one of the more versatile and rapid techniques for handling small parts with only the disadvantage of their inability to handle some shapes. Although a vacuum-probe unit is required for every operator (at a cost of $\$ 100$ each), a saving of five minutes per day in handling will easily pay for such a unit in a year's time (Table 3 ). These units (manufactured by Techni-Tool Inc., Plymouth Meeting, Pennsylvania) can lift up to 16 ounces $(4.448 \mathrm{~N})$ and have the added advantage of being usable for cleaning small particles from the surfaces of the parts.

The usefulness of vacuum probes is somewhat limited when parts must be pushed onto or pulled from fixtures. Tight-fitting pins may require the use of more than a 1 -pound $(4.448 \mathrm{~N})$ force. As the part size decreases, the probe area must also decrease which; in turn, decreases the available lifting force.

As previously stated, the production of parts in strips eliminates many handling problems. Also, the fixturing of each part on a small pallet and leaving the part on the pallet until the final machining operation has been completed can be used to minimize handling problems and the time involved. However, even though the pallets are small, they must be larger than the parts, and the tooling costs involved are therefore high; the addition of tooling bosses to the parts will accomplish the same objective at a much lower cost.

Bowl-feeders and the associated tracks for orienting parts can be used effectively for large lots (from 3000. to 1,000,000 parts, for example), but the required setup time will outweigh any saving in handling time for lots smaller than 500 parts. Miniature pick-and-place robots, used in conjunction with bowl-feeders and cassette programming, also can be effectively employed for large lots. The use of these devices has been described in more detail by other authors. 15,16 
Table 6. Approaches to the Handling of Miniature Parts

\begin{tabular}{|c|c|c|}
\hline Approach & Advantages & Limitations \\
\hline Use of Fingers & No tool cost & Cannot grasp minute parts \\
\hline Hand Tweezers & Low tool cost & $\begin{array}{l}\text { Relatively slow; can } \\
\text { damage very soft parts }\end{array}$ \\
\hline Hand Magnet & Low tool cost & $\begin{array}{l}\text { Parts must be magnetic; } \\
\text { residual magnetism must } \\
\text { be overcome }\end{array}$ \\
\hline Hand Vacuum Probes & $\begin{array}{l}\text { Easily picks up and } \\
\text { releases small, flat } \\
\text { parts; not affected by } \\
\text { material; no part } \\
\text { damage }\end{array}$ & $\begin{array}{l}\text { Not well suited for } \\
\text { picking up surfaces } \\
\text { having a radius }\end{array}$ \\
\hline Parts in Strips & $\begin{array}{l}\text { Convenient for handling } \\
\text { with fingers }\end{array}$ & $\begin{array}{l}\text { Some part-geometry } \\
\text { limitations }\end{array}$ \\
\hline Pallets & $\begin{array}{l}\text { Convenient for handling } \\
\text { by hand }\end{array}$ & $\begin{array}{l}\text { Requires one fixture per } \\
\text { part per lot }\end{array}$ \\
\hline Bowl Feeders & $\begin{array}{l}\text { Fast; low cost; feeder } \\
\text { can orient as well as } \\
\text { feed parts }\end{array}$ & $\begin{array}{l}\text { Transporting from feeder } \\
\text { to fixture requires } \\
\text { separate tooling for } \\
\text { each part; longer setup } \\
\text { times than by hand; } \\
\text { noticeable tool } \\
\text { clearance or additional } \\
\text { device to keep feeder } \\
\text { track out of cutter's } \\
\text { path }\end{array}$ \\
\hline Pick-And-Place Robots & Fast & $\begin{array}{l}\text { Not well suited for short } \\
\text { runs of widely differing } \\
\text { parts }\end{array}$ \\
\hline
\end{tabular}


Table 6 Continued. Approaches to the Handling of Miniature Parts

\begin{tabular}{llc}
\hline Approach & Advantages & Limitations \\
\hline Pneumatic Conveyors & Low cost & $\begin{array}{c}\text { Not economically suitable } \\
\text { for low-volume runs of } \\
\text { widely varying part } \\
\text { geometries }\end{array}$ \\
Tooling Bosses & No measurable material & $\begin{array}{l}\text { Not suitable for all part } \\
\text { geometries; requires two } \\
\text { additional operations }\end{array}$ \\
\hline
\end{tabular}


For large lots, air sometimes may be used to move parts from one station to another. As noted by Green, 17 one company blows small screw-machine parts through flexible pipelines from one process to the next. This approach improved the workflow between machines by replacing the batch-handling of parts in containers, thereby eliminating transit damage and handling time. Unfortunately, this approach is not applicable to small quantities of parts or to parts having widely varying geometries.

One particular area which can require large amounts of handling time is the removing of miniature parts from loose-abrasive deburring media. Processes such as vibratory deburring or centrifugal-barrel finishing útilize random-shaped nuggets which often are approximately the same size as the workpieces. Thus the screening of nonmagnetic parts from nonmagnetic media of the same size can require extraordinary amounts of time. As an example, one-hundred 0.020 -inch-diameter $(0.5 \mathrm{~mm})$ pins placed in two quarts of wet Number 24 media (approximately 0.030 inch or $0.75 \mathrm{~mm}$ in diameter) will require at least four hours to sort by hand. In contrast, the deburring of such parts by use of the harperizer would require only 40 minutes. Although none of the existing commercial sorting-equipment is capable of sorting such a combination and still accommodating a wide variety of other part configurations and sizes, the following three approaches can be used to minimize this problem:

The amount of media used for deburring can be reduced;

Special screens can be purchased in sizes that will sort out all media except those which are exactly equal to the size of the part; and

Vibratory feeders can be used to sort the small volume of mixed parts and media that is left from the previous approach.

The first of these approaches permits the operator to search through less media to find the same number of parts; thus handling is reduced in proportion to the amount of media used.

Although the separation of any proportion of media from the parts is advantageous, the standard screen sizes will not provide significant separation of the parts from some media. By utilizing special screens with openings which are graduated every 0.005 inch $(127.0 \mu \mathrm{m})$, most of the media can be quickly removed. With only a small amount of media remaining, vibratory feeders with special separator gates can quickly provide the final separation.

\section{Implementation of Fixturing and Handling Approaches}

The majority of the fixturing and handiing techniques described in this report have been utilized at Bendix Kansas City to produce parts. While some techniques have unique applications, 
others can be used for many types of applications. Tooling bosses such as those shown in Figure 4 are now being used for many small parts because they provide for easy handling and eliminate cumbersome, restrictive clamping. Furthermore, in most cases, they eliminate the need for special holding fixtures since standard colleting equipment is readily available.

The use of strips of parts and oversize blanks having tooling holes external to the parts are also used, but these approaches typically offer no advantage over tooling bosses when N/C equipment is used unless orientation of the parts between machining operations is required.

Adhesives are being used to hold ceramic-base integrated circuits for cutoff. They also have been used for holding metal parts, but not extensively. Vacuum chucks have been used to some extent, but the majority of small parts do not have sufficient surface area to provide an adequate holding force; the same is true of electrostatic chucks.

The removal of thin parts from magnetic chucks is difficult because of residual magnetism in the parts. Like vacuum and electrostatic chucks, magnetic chucks also require a certain amount of surface area, since several laminations in the magnetic chucks must be bridged to provide an adequate holding force.

Vacuum probes have been used for the handling of small parts, but, as previously indicated, they often do not provide adequate force for placing parts on fixtures. The recently introduced pencil-type magnets which provide a total magnetic release are currently being used for handing magnetic parts.

\section{ACCOMPLISHMENTS}

Fixturing and handling techniques which are applicable to the production of miniature precision parts have been identified. Most of these have been employed at the Bendix Kansas City Division for production lots of parts. The use of tooling bosses has proven to be one of the most versatile and economical approaches to the fixturing and handling of miniature parts. Pencil-type magnets with built-in release mechanisms also have alleviated some of the handling problems. 


\section{REFERENCES}

${ }^{1}$ L. K. Gillespie, Machining Miniature slots and. Fillets (Final Report). UNCLASSIFIED. Bendix Kansas City: BDX-613-576, April, 1972 (Available from NTIS).

${ }^{2}$ L. K. Gillespie, Profize Mizzing (Topical Report). UNCLASSIFIED. Bendix Kansas City: BDX-613-980 Rev., May, 1974 (Available from NTIS ).

${ }^{3}$ "News Digest," Production, June, 1972, p 7.

"Machining of Parts in Metal Strips," Microtechnic, Number 4, 1972 .

s"Plastic Tooling for Stainless Steel Parts," Manufacturing Engineering and Management, July, 1970, pp 26-27.

${ }^{6} \mathrm{C}$. Carl Wilson, "Effect of Operating Parameters on Cutter Horsepower in Face Milling," Proceedings of the International Conference on Manufacturing Technology. Dearborn, Michigan: ASTME (Now SME), 1967, pp 525-532.

${ }^{7}$ G. S. A. Shawki and M. M. Abdel-Aal, "Rigidity Considerations in Fixture Design--Contact Rigidity at Locating Elements," International Journal of Machine Tool Design and Research, Volume 6 , 1966, pp 31-43.

${ }^{8}$ Frank W. Wilson, Handbook of Fixture Design. New York: McGraw$\mathrm{Hill}, 1962$.

${ }^{9} M$ achining Data Handbook (Second Edition). Cincinnati: Machinability Data Center, 1972, pp 869-881.

${ }^{10} \mathrm{~F}$. Wilson, editor, Tool Engineer's Handbook (Second Edition). Dearborn, Michigan: ASTME (Now SME), Chapter 18.

${ }^{1}$ Amitabha Bhattacharyya and Inyong Ham, Design of Cutting Tools. Dearborn, Michigan: ASTME (Now SME), 1969.

${ }^{12} \mathrm{O}$. W. Boston and W. W. Gilbert, "The Torque and Thrust of Small Drills Operating in Various Metals," ASME Transactions, Volume 58, Number 1, 1936, pp 79-89.

${ }^{13}$ Andor Horning, "Slab Milling Efficiency," Tool and Manufacturing Engineer, May, 1969, pp 59-62.

${ }^{14}$ R. S. Hahn, "On the Nature of the Grinding Process," Paper presented at Second International Production Conference, Birmingham, England, September, 1962. Also see "Grinding Fundamentals--II," International Research in Production Engineering. New York: ASME, 1963 , p 207 . 
15 "Simple Automation Cuts Cost 92.5\%," American Machinist, May 27, $1974, \mathrm{p} 41$.

16 "Trends in Part Feeding," Tooling and Production, September, 1974, pp 34-37.

${ }^{17}$ Richard G. Green, "In-Process Handling," Automation, November, 1974, pp 80-87. 


\begin{abstract}
Appendix
BENDIX-MADE PARTS PRESENTING

UNIQUE HANDLING AND FIXTURING PROBLEMS
\end{abstract}



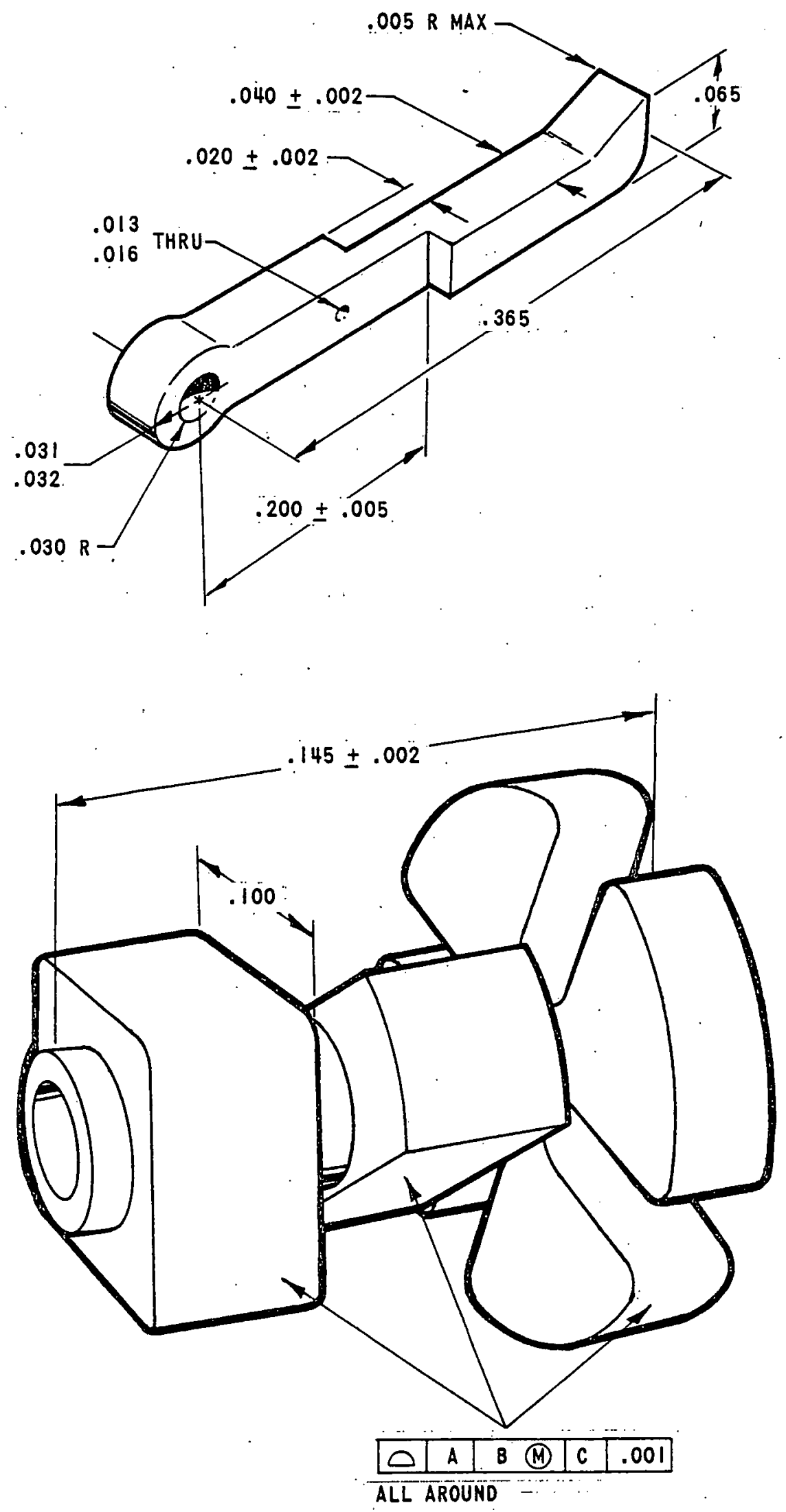


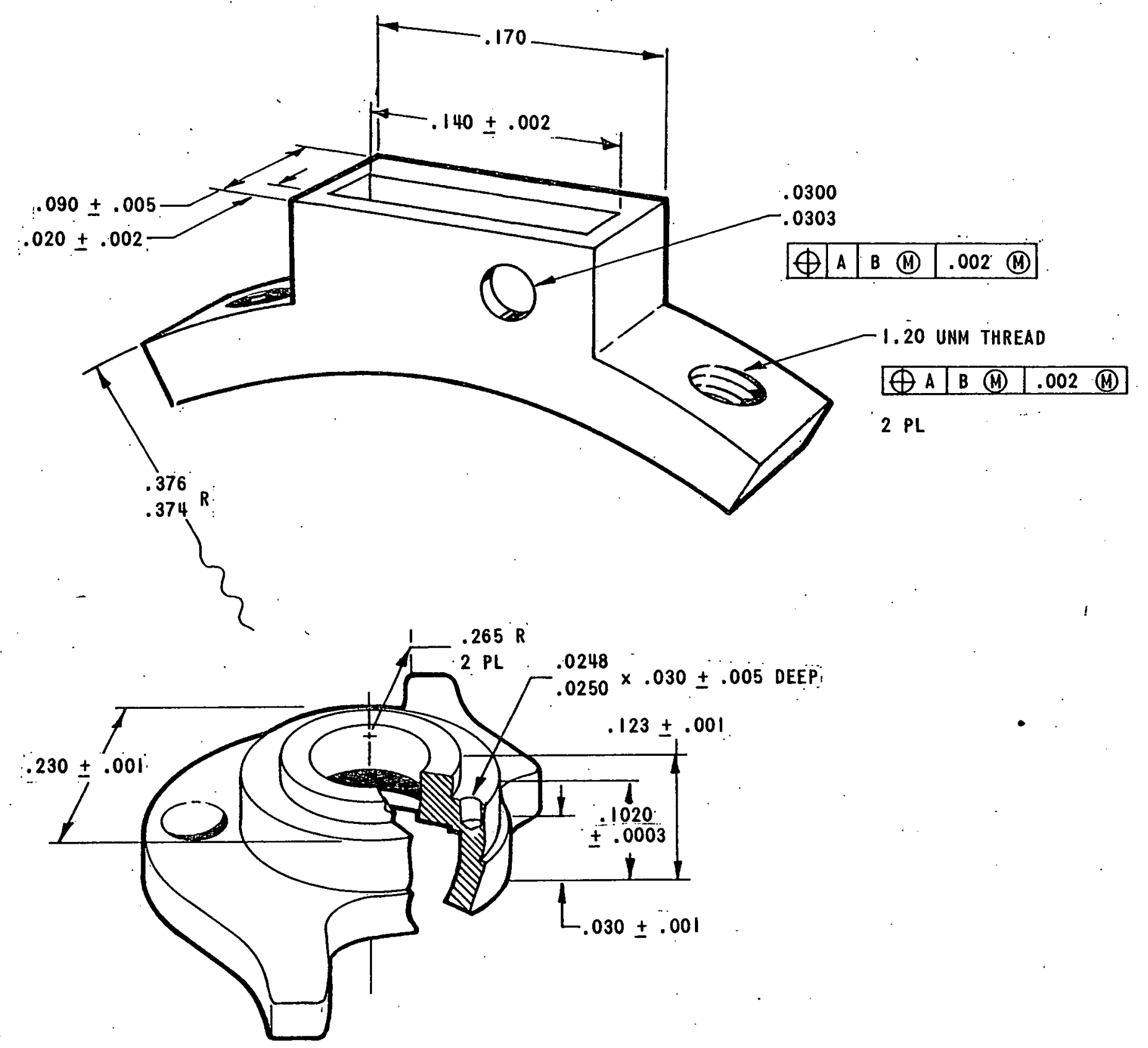




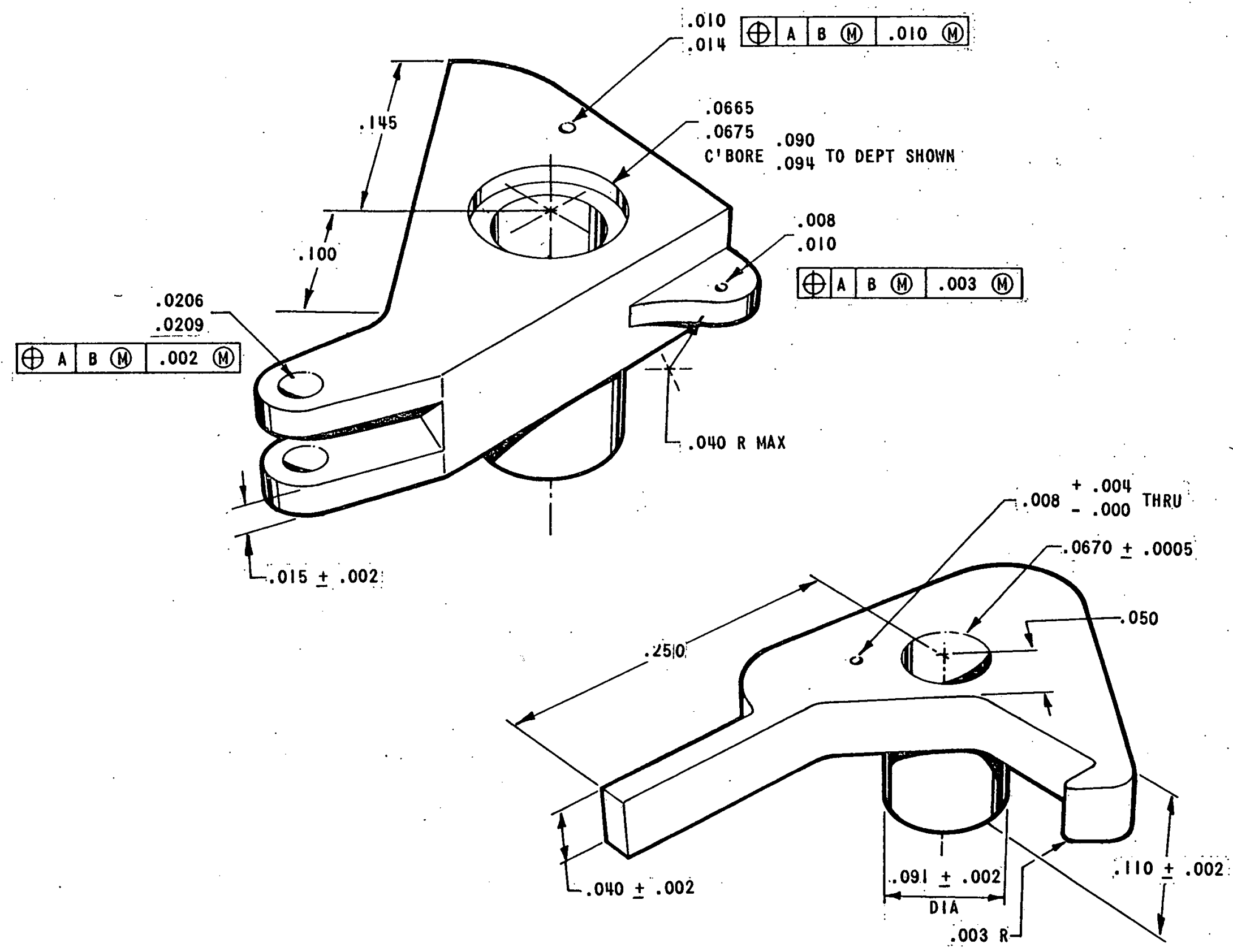




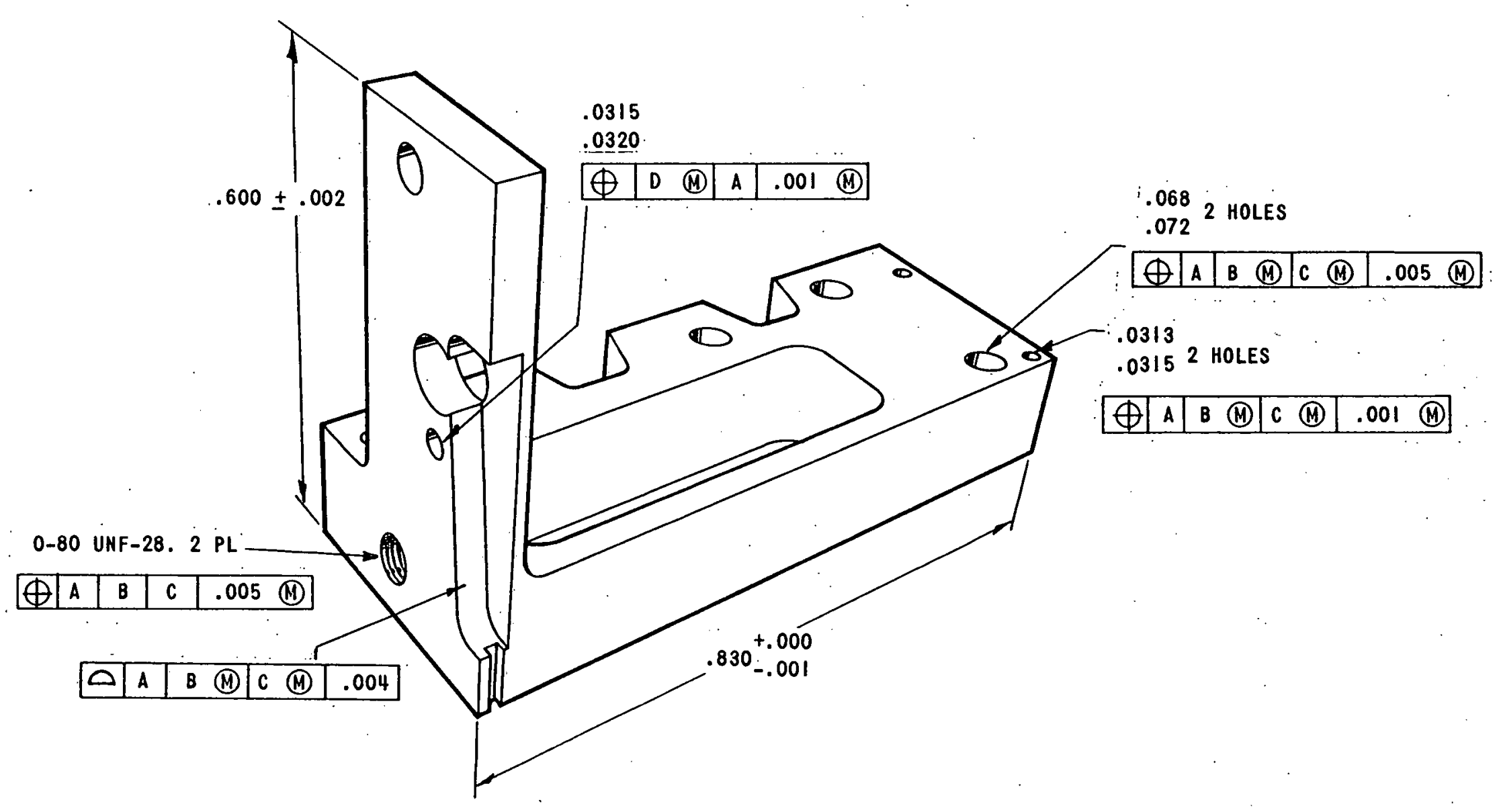



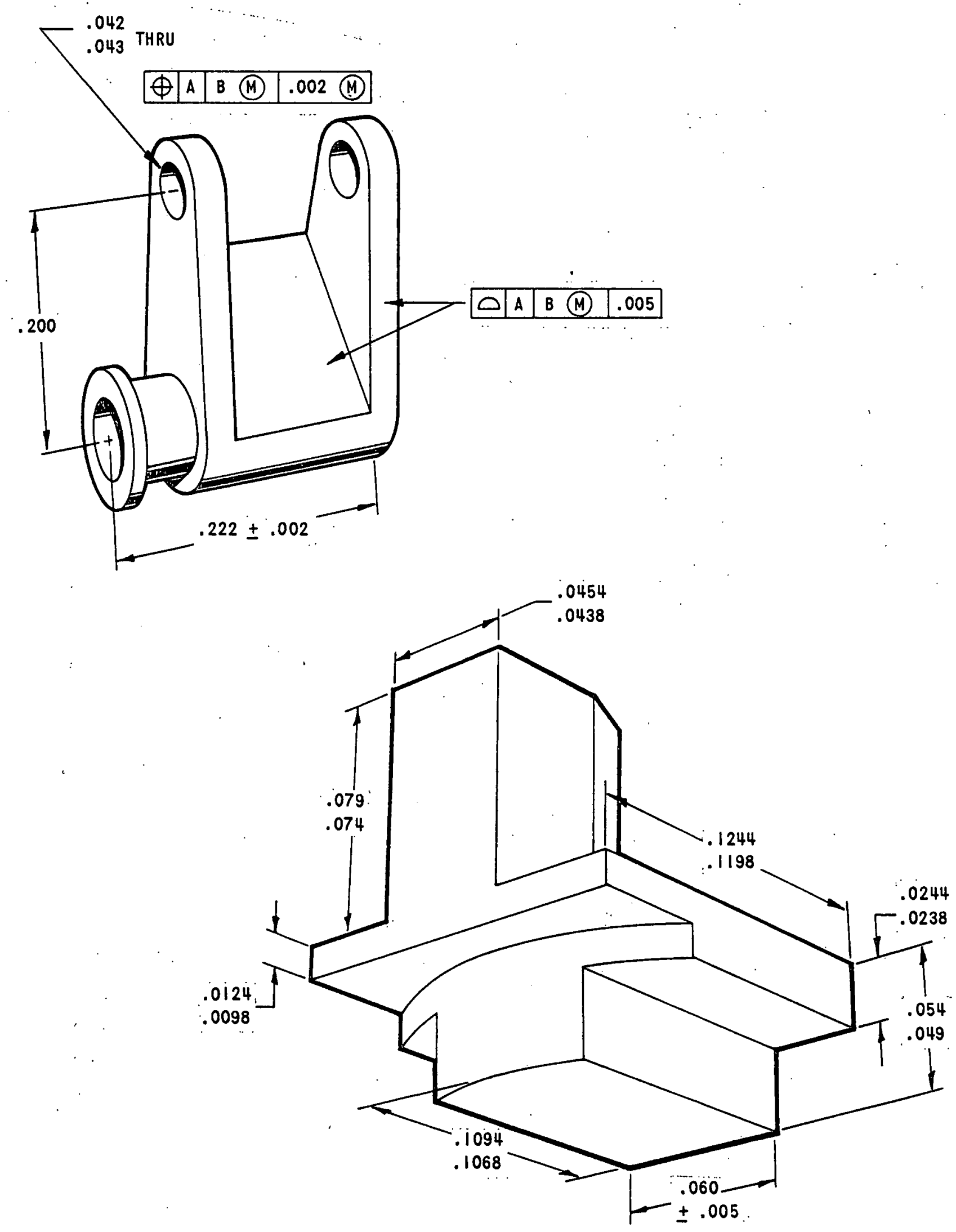


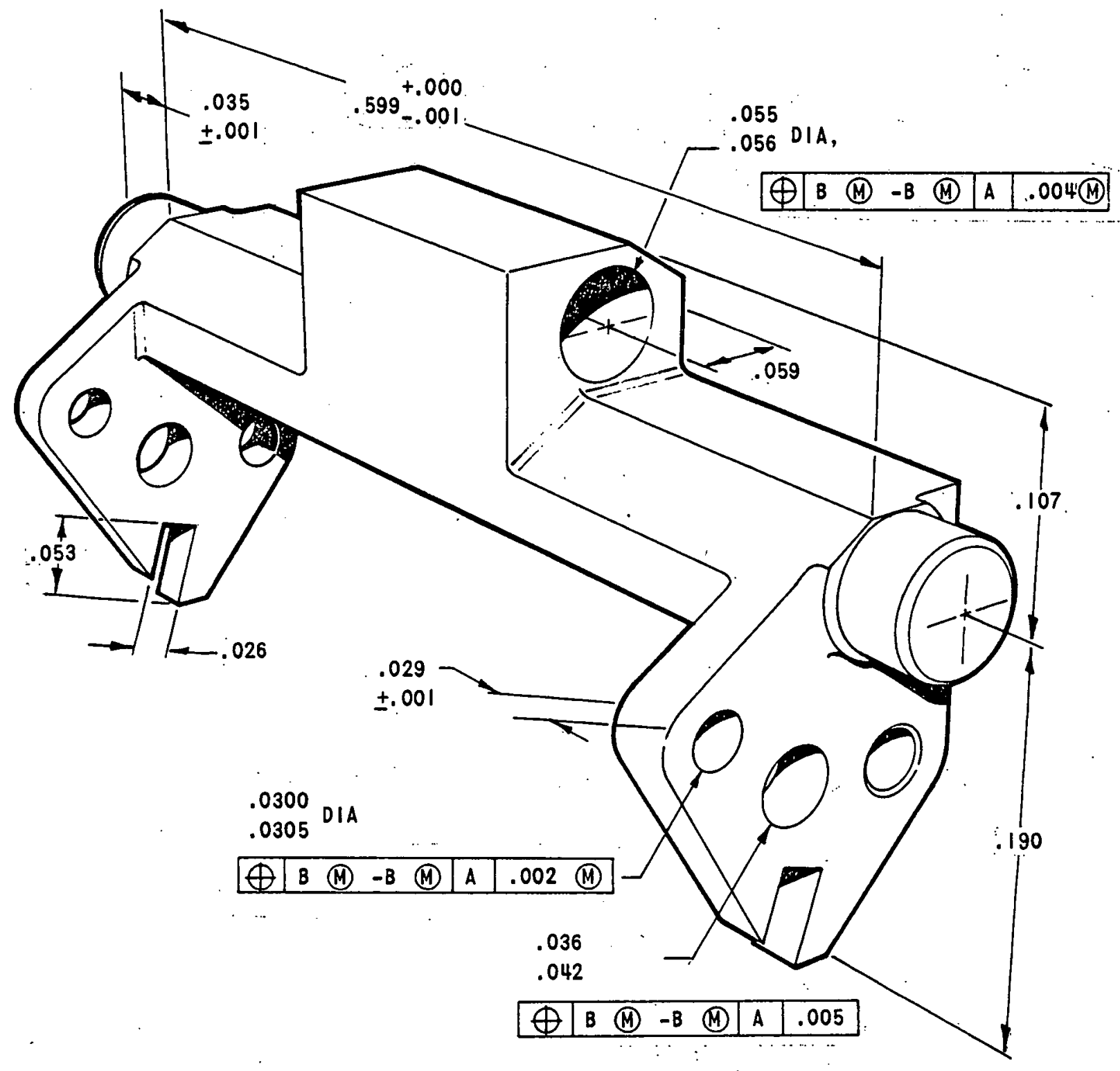




\section{DISTRIBUTION}

Copy

R. Bulcock, ERDA-KCAO, $1 \mathrm{D} 49$

A. A. Kenly; Pinellas

J. W. Baker, Rockwell

K. Thistlewood, Rockwell

J. Ford, SLA

K. Gillespie, SLA

R. Pinkham, SLA

A. Thornton, SLA

1

2

3

4

5

6

7

8

W. A. Johaningsmeir, D/231, 1D40 9

H. L. Price, D/261, FU34

10

E. L. Young, D/261, FU34

11

J. D. Corey, D/554, BD50

$12-13$

L. Stratton, $\mathrm{D} / 554,2 \mathrm{C} 44$

$14-16$

R. F. Pippert, D/700, $1 A 42$

E. F. Felkner, D/752, $1 \mathrm{~A} 41$

J. D. Johnson, D/752, $1 A 41$

R. P. Frohmberg, D/800, 2 A39

J. A. Morrison, D/800; D. D. Oswald, J. P. Dycus,

D. R. Wachter, D/822, 2440

R. K. Albright, D/821, $2 \mathrm{~A} 36$

J. L. Couchman, B. W. Landes, F. Boyle,

W. G. Cooper, D/821, 2A36

L. K. Gillespie, D/822, $2 A 36$

G. E. Klement, D/822, $2 A 36$

C. P. Rome, D/822, $2 A 36$

C. E. Spitzkeit, D/823, $1 \mathrm{~A} 27$

R. W. Lange, D/861, 2 A31

R. E. Kessler, D/865, 2C40 